\title{
Application of a Justice as Fairness Perspective to Laws Banning Same-Sex Marriage
}

\author{
Rhonda R. Dobbs
}

The University of Texas at Arlington

\begin{abstract}
This paper utilizes John Rawls' theory of Justice as Fairness to assess laws banning same-sex marriage. It is argued that such laws are unjust from this perspective in that they do serve to disadvantage homosexuals in regards to the legal benefits of marriage. In addition, legal unions (i.e. domestic partnerships or civil unions) that stop short of marriage do not compensate for this unjustness in that they do not offer the same legal benefits of marriage.

(C) 2004 Californian Journal of Health Promotion. All rights reserved.

Keywords: same-sex marriage, justice as fairness, defense of marriage act, marriage
\end{abstract}

"The paradigmatic couple in Genesis is named 'Adam and Eve.' The representation is valid not just because it is in the Bible, but in the Bible because it is valid.” (Hart, 1996: 31)

"Conservatives say they abhor gay marriage because they value marriage. The truth is they abhor gay marriage because they abhor gays." (Chapman, 1996)

"Some countries cut off their [Gay] heads. We don't do that. What more do they want?" (Judd, 1997)

\section{Introduction}

"The freedom to marry has long been recognized as one of the vital personal rights essential to the orderly pursuit of happiness by free men" (U.S. Supreme Court: Loving v. Virginia, 1967).

Although the right to marry the person one loves and cares for has long been recognized as an essential liberty in this country, it is historically not a right that has been shared by everyone. Over time, however, marriage laws in this country have changed so that marriages once deemed immoral or unnatural are no longer proscribed by law, including marriages between people of different classes, religions, and races. Today the freedom to marry the person one loves is provided to all adults with the exception of homosexuals.

On May 5, 1993, the Hawaii Supreme Court handed down a landmark ruling (Baehr v. Lewin, 1993) declaring that the state must issue marriage licenses to same-sex couples unless they could prove a "compelling state interest" to not do (Mohr, 1997). In December 1996, a Circuit judge in Hawaii ruled (Baehr v. Miike, 1996) that the state had failed to prove such an interest and must begin to issue marriage licenses to same-sex couples (Baird and Rosenbaum, 1997). The state won a stay of execution of this order awaiting hearing of the appeal, meaning that they do not have to issue licenses to same-sex couples until the appeal is heard by the Hawaiian Supreme Court in early 1998. Based on past rulings of the Court in this matter, it was expected that same-sex marriages would be allowed and marriage licenses would be granted to same-sex couples shortly afterwards (Sullivan, 1997). In November of 1998, voters in Hawaii approved an amendment to the state constitution defining that restricted marriage to heterosexual couples. The Supreme Court in Hawaii subsequently ruled Baehr v. Miike moot due to the change in the state's constitution (HRC, 2004). Thus ended the first 
"great hope” of making a same-sex marriage a reality.

The debate over same-sex marriage heated up again in November 2003, when, in the case Goodridge v. Department of Public Health, the Massachusetts Supreme Court ruled that samesex couples should be allowed to obtain marriage licenses. The court gave the state legislature 180 days to amend the state's marriage laws to bring them into compliance with their ruling (HRC, 2004a). The Massachusetts legislature is currently in the process of addressing the issue of same-sex marriage and will reconvene on March 29 to vote on a measure that could send a constitutional amendment banning same-sex marriage to the voters of Massachusetts in 2006. Under the ruling of the Supreme Court, the state, however, is scheduled to begin issuing marriage licenses to same-sex couples on May 17, 2004 (Tuchman, 2004).

Under the direction of Mayor Gavin Newsom, the city of San Francisco began issuing marriage licenses to same-sex couples February 12, 2004 despite the fact that California does have a law banning same-sex marriage. Almost 4,000 such licenses were issued before the California Supreme Court ordered a halt to same-sex marriages on March 11, 2004 (CNN, 2004). The state Supreme Court is scheduled to hear oral arguments regarding same-sex marriage in May or June 2004. Following the actions of Mayor Newsom, other cities also began issuing marriage licenses to same-sex couples, including Portland, Oregon, New Paltz, New York, Asbury Park, New Jersey, and Sandoval County, New Mexico. Legal challenges to these marriages have been filed in each of these jurisdictions (CNN, 2004). Also following the actions of Mayor Newsom, President Bush called for an amendment to the U.S. Constitution that would define marriage as a union between one man and one woman (CNN, 2004). Clearly, then, the debate over same-sex marriage is currently in full swing and is likely to remain a principal issue in this election year.

\section{Defense of Marriage Acts}

Legally, marriage has traditionally been a statelevel matter in the United States with each state enjoying the power to grant marriage licenses and stipulate what qualifications people must meet in order to obtain those licenses. Although these qualifications differ from state to state, along factors such as age and closeness of familial relationship, each state now recognizes legal marriages from other states, even if those involved would not meet their own qualifications. This recognition of marriage across states is required by the Full Faith and Credit Clause of the U.S. Constitution, which obligates states to honor "the acts, records, and judicial proceedings" of the other states unless those laws are in violation of their own legitimate public policy (Infanti, 1997: 232).

The possibility that same-sex marriage might be legalized in some states and the understanding that such marriages would have to be recognized by the remaining states under the Full Faith and Credit Clause unless such marriages were outlawed in those states has led to strong and swift reactions from conservative groups and anti-gay activists. Such groups joined together to inaugurate the National Campaign to Protect Marriage, a movement that has been instrumental in the introduction and passage of so-called Defense of Marriage Acts (DOMA) federally and at the state level. As of February 2004, DOMA or other laws banning same-sex marriage have passed into law at the federal level and in at least 38 states (see Table 1). 
Table 1

States with Laws Banning Same-Sex Marriage

\begin{tabular}{|l|l|l|l|l|}
\hline Alabama & Georgia & Maine & North Carolina & Utah \\
\hline Alaska* & Hawaii* & Michigan & North Dakota & Virginia \\
\hline Arizona & Idaho & Minnesota & Ohio & Washington \\
\hline Arkansas & Illinois & Mississippi & Oklahoma & West Virginia \\
\hline California* & Iowa & Missouri & Pennsylvania & \\
\hline Colorado & Kansas & Montana & South Dakota & \\
\hline Delaware & Kentucky & Nebraska* & Tennessee & \\
\hline Florida & Louisiana & Nevada* & Texas & \\
\hline
\end{tabular}

*Ballot initiatives banned same-sex marriages in these 5 states; the other 33 states banned same-sex marriage through laws passed by the legislature. Source: Lambda Legal Defense and Education Fund. 2004. "States with Laws Banning Same-Sex Marriage.” Accessed online March 14, 2004, http://www.lambdalegal.org/cgi-bin/iowa/documents/record?record=1427

President Clinton signed into law the federal DOMA on September 21, 1996 after it had easily passed both the House and Senate. DOMA passed in the House by a vote of 342-87 and in the Senate by a vote of $85-14$ (Mohr, 1997). At the federal level, DOMA accomplishes two objectives (Baird and Rosenbaum, 1997). First, it allows states to refuse to recognize same-sex marriages legalized in other states (DOMA, 1997). In the case of same-sex marriage, then, states have explicitly been given the right to waive the Full Faith and Credit Clause of the Constitution and refuse to honor marital contracts bestowed in other states. Through the passage of their own anti-marriage laws, 38 states have already exercised that right even though same-sex marriage has yet to be legalized in any other state.

The second objective of the federal DOMA is to render a federal definition of the terms marriage and spouse. Marriage is defined as "a legal union between one man and one woman as husband and wife" and a spouse is defined as "a person of the opposite sex who is a husband or a wife" (DOMA, 1997: 18). The implications of this portion of DOMA are that all federal rights and benefits given to legal spouses do not and will not apply to same-sex couples, even if they are allowed to legally marry in any of the 50 states. Notwithstanding recognition of same-sex marriage by Hawaii or any other state(s), the federal government does not and will not recognize same-sex marriages.
Although the rhetoric around the support of DOMA is that it generally serves to protect the institution of marriage, the principle effect of the legislation is that same-sex couples are continued to be denied the basic rights, benefits, and protections provided by marriage. Even if Hawaii legalizes same-sex marriages, these couples will still be denied these federal rights and protections along with the recognition of their marriages (Carl, 1997). Six months after passing DOMA, Congress asked the congressional General Accounting Office (GAO) to investigate and determine what legal marriage means under federal law, that is, to determine what it is that they denied to same-sex couples (Byron, 1997). The GAO concluded that there were at least 1,049 laws that addressed marital status in some form, many of these providing federal benefits and protections to married partners in various categories, including Social Security programs, veterans' benefits, taxation, and employment benefits (GAO, 1997).

While each of the DOMA passed at the state level differs slightly, there are two principle purposes of these state-level acts. First, all statelevel DOMA specify that same-sex marriages performed in other states will not be legally recognized. That is, states that have passed these acts are exercising their right to suspend the Full Faith and Credit Clause in the case of same-sex marriages. The second objective of these state-level DOMA is to stipulate that same-sex couples will not be allowed to marry 
in that state. This is a stipulation that is unnecessary in the DOMA of most states, since such marriages were already prohibited.

Homosexual couples in this country have never enjoyed the same opportunities and rights of marriage as have heterosexual couples. And, in fact, the mere possibility that same-sex couples might obtain the same opportunities and rights as heterosexual couples in terms of legal marriage has led to the passage of legislation denying these rights before they were ever conferred.

\section{Justice as Fairness, Marriage and DOMA}

According to Rawls theory of Justice as Fairness, a well-ordered society is typified as "a scheme of cooperation for reciprocal advantage regulated by principles which persons would choose in an initial situation that is fair" (Rawls, 1971: 33). The general conception of Rawls' notion of justice is twofold. First and foremost, Rawls (1971) argues that everyone should have equal liberty of opportunity. Second, any inequalities which do exist in the distribution of these liberties and opportunities are to be to the advantage of the least favored while not disadvantaging anyone else. This is what Rawls (1971) refers to as the difference or maximin principle.

In order to apply the two principles of justice in assessing the justness of legislation and social policies, Rawls (1971) sets up a four-stage sequence. The first three stages of this sequence, the original position, the constitutional convention, and the legislative stage, correspond to three cardinal questions that should be addressed concerning the distribution of marital opportunities and rights. First, what characteristics would a just distribution of marital rights possess? Second, to what extent is the state responsible for honoring legal contracts? Lastly, is legal discrimination based on personal characteristics, such as sex, race, and sexual orientation just? According to Rawls (1971), laws and policies are just if they are what a rational person would choose at the appropriate stage in the sequence.
In addressing the first question concerning what characteristics a just distribution of marital rights might possess, it is necessary to understand Rawls' notion of the concepts of the original position and the veil of ignorance. It is in the fair initial situation, or the original position, that people contract with one another as to the distribution of primary goods that will exist in society. While in the original position, people are under the veil of ignorance in which they know nothing about their own position and interests in society, however, they do know "the actual distribution of circumstantial and genetic traits among persons in society" (Roemer, 1996: 173). Since Rawls (1971) assumes people to be rational, he argues that they will choose the distribution that is most likely to give them the opportunity for more primary goods rather than less. Not knowing what their exact position and interests are, he argues that the distribution people in the original position will choose is one that meets his two principles of justice: 1) equal liberty and 2) inequalities that benefit the least advantaged, while not disadvantaging anyone else. In other words, not knowing what their positions and interests are, people will choose rules that apply equally to everyone, not just to some.

The first step in understanding the distribution of any social good from this perspective is to assess what distribution of that good would be chosen by people in the original position. In terms of marriage, the knowledge that people in the original position would posses is twofold. First, they know that marriage is defined as a social good only when a person is free to decide to marry whom they choose. Second, they know that there will be heterosexuals and homosexuals in society, that is, they know the circumstantial and genetic traits that will exist in society. What they do not know is their own position and interests in society. I would argue that a rational person under these circumstances would choose equal liberty to marry for both groups, giving themselves the best possible chance to enjoy the right to marry as part of their life plan.

According to Rawls (1971), liberty is unequal when one class of people has greater liberty than another. Rawls (1971) contends that people are 
at liberty to do something when they are free from certain constraints either to do or not to do it and when doing it or not doing it is protected from interference of others. Considering this first question, then, it appears that DOMA would not be considered just from this perspective since such acts serve to prohibit homosexuals from marrying. In other words, the ability of homosexuals to marry whom they choose is constrained by the state, meaning that they do not share the same liberty to marry that heterosexuals do. The first principle of justice, then is not met by DOMA. In and of itself, this does not mean that the distribution of marital rights stipulated by DOMA is necessarily unjust, however, it does provide evidence of its unjustness. In order to determine the overall justness of DOMA, subsequent stages in the sequence must be considered as well as the second principle of justice.

The second question to consider from this perspective concerns the extent to which the state is responsible for assuring that contracts are honored. In dealing with this question, it is useful to understand Rawls' conception of the constitutional convention, which is the stage that follows the original position in his four-stage sequence. During this stage, the veil of ignorance is lifted somewhat so that those involved know slightly more about society in this stage than they do in the original position, however, they still know nothing about their own position and interests. It is at this stage that the basic rights of citizens are chosen as well as the constitutional powers and responsibilities of the government.

Rawls (1971) contends that one of the responsibilities of the state is to maintain the stability of social cooperation. Part of this maintenance of stability involves enforcement of the rules of the society.

"It is reasonable to assume that even in a wellordered society the coercive powers of government are to some degree necessary for the stability of social cooperation. For although men know that they share a common sense of justice and that each wants to adhere to the existing arrangements, they may nevertheless lack full confidence in one another. They may suspect that some are not doing their part, and so they may be tempted to not do theirs" (Rawls, 1971, 240).

Coercion, then is the way the state compensates for the lack of confidence that people may have in one another in fulfilling their part in society. Knowing that people may lack confidence in one another's cooperative abilities, rational people in the constitutional convention would allow the possibility of state coercion in order to best ensure that their own liberties will not be infringed upon by others. One area in which confidence is particularly important from this perspective is in contractual relationships. In order for society to work properly, people must be willing to enter into contractual relationships with one another for mutual advantage. People will be willing to do so only when they believe that these contracts that are entered into knowingly and freely will be honored. Barring this assurance, it is likely that people will be less willing to enter into contractual relationships with one another. It is rational, then, that part of the state's power of coercion would encompass some way of providing assurance that contractual relationships will be honored, thereby fostering people's confidence in the fidelity of contracts. From a justice as fairness perspective, then, one of the responsibilities of a just state chosen in the constitutional convention would involve the recognition and preservation of legal contracts. I would argue that the state's ability to foster such confidence is undermined to the extent that they do not recognize contracts that are legally established.

Since marriage is best understood as a legal contract between two people and the state, when such relationships are entered into legally, they should be recognized by the state as would any form of legal contract. To allow the state to circumscribe one type of contract, such as legalized same-sex marriages, may serve to increase people's lack of confidence in one another and in the stability of contracts rather than fostering confidence in such relationships. Also, if the state is allowed to ignore certain contracts, then it may become easier for individuals to rationalize their own breach of 
contractual relationships. In other words, if the state is allowed to refuse to recognize contracts for certain people that it recognizes for others, all other contracts are placed in potential jeopardy of not being honored, either by individuals or by the state. Addressing this question points out another way that DOMA could be considered unjust from this perspective. Since these acts allow states to refuse to recognize marital contracts that are legally entered into, they are in contention with the principle that states should foster people's confidence in one another and in the state by assuring that legal contracts are honored.

The third question that must be addressed from a Justice as Fairness perspective concerns the sanctioning of legal discrimination based on personal characteristics, such as sex, race, and sexual orientation. This question may be best addressed from the legislative stage of Rawls' sequence. At this stage, the veil of ignorance is lifted slightly more than in the previous two stages so that more is known about society as a whole, including the "hierarchies of political, economic, and social forms" necessary for social cooperation, yet individuals still do not know their own position and interests in society (Rawls, 1971: 199). According to Rawls (1971), this stage is most concerned with the difference or maximin principle, or with assessing whether or not the least favored benefit from the distribution regardless of their disadvantaged position.

It is unlikely that rational actors would choose to allow laws to be passed that discriminated based on personal characteristics at this stage unless those groups discriminated against benefited in some way from this discrimination. The first reason that such discrimination would not be chosen at this stage is that it directly contradicts Rawls' first principle of justice, equal liberty, which is always lexically prior to the difference principle. Such discrimination also has the potential to contradict the second principle of justice, that the least advantaged are to benefit from any inequalities that exist. It is unlikely, then, that rational people in the legislative stage would allow for some groups of people to be given fewer rights than others based solely on personal characteristics without knowing that those groups would still gain. If, however, the groups of people that are given fewer rights under the law benefit from their disadvantage, this differential distribution of rights would not necessarily be unjust, as long as no other group was benefiting from their disadvantage. If some other group is benefiting from this discrimination, then this leads to a separate problem with such discrimination, namely, the potential of allowing some groups to benefit from their natural attributes, which is not allowed from a Justice as Fairness. To "say that human beings are equal is to say that none have a claim to preferential treatment in the absence of compelling reasons” (Rawls, 1971: 507).

In terms of the distribution of marital opportunities, rational actors at this stage would know the hierarchical ordering of heterosexuals and homosexuals in relation to one another, that is, they would know that heterosexuals would be the majority in terms of number and in terms of rights. What people at the legislative stage would still not know is their own position and interests. I would argue that rational actors at this stage would still opt for equal access to marital opportunities for both groups to marry whom they choose, thereby giving themselves the best possible chance to include marriage as part of their life plan. If unequal access to marital opportunities would not disadvantage the group without access, then such unequal access might be chosen at this stage and would not necessarily be considered unjust. However, to the extent that DOMA serve only to prohibit same-sex couples to marry, they would be considered unjust from this stage of a Justice as Fairness perspective since they deny rights to a certain group while not advantaging that group.

In order to compensate for the lack of legal rights associated with marriage, several local governments and at least one state (Vermont) have legally recognized same-sex relationships, or domestic partnerships in some capacity. Domestic partnerships apply to unmarried opposite-sex couples as well as to same-sex couples. The implicit purpose of such recognition is to provide same-sex couples with the privileges of legal marriage even though they 
are not allowed to legally marry. To the extent that this recognition translates into the extension of the benefits of legal marriage to same-sex couples, acts that prohibit legal marriage could be considered just from this perspective as long as opposite-sex couples were not being advantaged as a result of the denial of same-sex marriage. However, in the majority of cases, the recognition of same-sex relationships is nothing more than mere recognition. For example, Vermont's recognition provides only one benefit to same-sex couples - health insurance coverage for partners of state workers (Mohr, 1997). So, there are no automatic rights and benefits associated with such recognition as there are with legal marriage. In some instances, this recognition may make it easier for these couples to legally arrange for some of the automatic benefits of marriage, such as hospital visitation and medical decision-making, however, these benefits are not guaranteed as they are to legally married persons.

On the whole, domestic partnership laws provide nothing close to the benefits of legal marriage to same-sex couples. As shown in Table 2, most of the benefits that automatically come to legally married couples are denied to same-sex couples in spite of domestic partnership laws (Mohr, 1997). In other words, domestic partnership laws are not serving to benefit same-sex couples. To the extent that this is true, the existence of domestic partnership laws do nothing to make DOMA more just since same-sex couples are denied the opportunities, rights, and benefits of legal marriage.

Table 2

Selected Benefits Associated with Legal Marriage and Domestic Partnership

\begin{tabular}{|l|l|l|}
\hline \multicolumn{1}{|c|}{ State-Level Benefits: } & Legal Marriage & \multicolumn{1}{|c|}{ Domestic Partnership } \\
\hline Assumption of Spouse's Pension & Automatic & No \\
\hline Burial Determination & Automatic & No \\
\hline Various Property Rights & Automatic & No \\
\hline Child Custody & Automatic & No \\
\hline Crime Victim's Recovery Benefits & Automatic & No \\
\hline Divorce Protections & Automatic & No \\
\hline Domestic Violence Intervention & Automatic & In selected jurisdictions \\
\hline Inheritance & Automatic & $\begin{array}{l}\text { No - Will necessary and is } \\
\text { contestable }\end{array}$ \\
\hline $\begin{array}{l}\text { Immunity from Testifying Against } \\
\text { Spouse }\end{array}$ & Automatic & No \\
\hline Insurance Breaks & Automatic & No \\
\hline Joint Adoption and Foster Care & Probable & No - Prohibited in some states \\
\hline Joint Parenting & Automatic & No \\
\hline $\begin{array}{l}\text { Medical Decisions on Behalf of } \\
\text { Partner }\end{array}$ & Automatic & $\begin{array}{l}\text { No - Physician's directives or } \\
\text { powers of attorney are } \\
\text { necessary }\end{array}$ \\
\hline $\begin{array}{l}\text { Visitation of Partner in Hospital } \\
\text { (ICU) }\end{array}$ & Automatic & $\begin{array}{l}\text { Often prohibited. Physician's } \\
\text { directives or powers of } \\
\text { attorney must be drawn }\end{array}$ \\
\hline Wrongful Death Benefits & & No \\
\hline Federal-level Benefits: & Automatic & No \\
\hline Immigration & Automatic & No \\
\hline Social Security Survivor Benefits & Automatic & Pars \\
\hline
\end{tabular}

Source: "Comparing Legal Marriage/Ceremonial Marriage/Domestic Partner Benefits.” Partners Task Force for Gay and Lesbian Couples. 1997. Internet Homepage: http://www.buddybuddy.com/m-comp.html 


\section{Conclusion}

I contend that Defense of Marriage Acts are unjust from a Justice as Fairness perspective for at least three reasons. First, such acts do not meet either of the two principles of justice established by Rawls. In violation of the first principle of equal liberty, such acts serve to deny the opportunity of legal marriage to same-sex couples. While this in and of itself is not enough to warrant a conclusion of unjustness, these acts also fail to meet Rawls' second principle of justice. The inequalities in the opportunity to marry are not justified in that same-sex couples do not any measure of advantage from the distribution, in fact, they are disadvantaged by it. Lastly, such acts would be considered unjust because their denial of legal contracts has the potential of weakening the bonds of other contractual relationships, which are the very essence of a well-ordered society from this perspective.

Marriage is a social good that should be provided to same-sex couples. Doing so provides them with the basic opportunities, rights, and benefits that they are currently denied. And, contrary to arguments of proponents of DOMA, extension of marital opportunities to same-sex couples does nothing to harm the benefits and rights of heterosexual married couples.

\section{References}

Baird, R. M., and S. E. Rosenbaum. (1997). Same-sex marriage: The moral and legal debate. NY: Prometheus Books.

Carl, D. (1997). Counseling same-sex couples. In R. M. Baird and S. E. Rosenbaum (Eds.), Same-sex marriage: The moral and legal debate (pp. 44-56). NY: Prometheus Books.

Chapman, S. (1996). Unspeakable Unions? - The Flimsy Case Against Gay Marriage. The Chicago Tribune, January 25.

CNN.com. (2004). California court halts same-sex marriages. CNN.com. Retrieved March 14, 2004, from http://www.cnn.com/2004/LAW/03/11/gay.marriage.california/

Demian. (1997). Comparing legal marriage/ceremonial marriage/domestic partner benefits. Partners Task Force for Gay and Lesbian Couples. Retrieved March 14, 2004, from http://www.buddybuddy.com/mar-comp.html

GAO. (1997). GAO report on the defense of marriage act. GAO/OGC-97-16, January 31, 1997.

Hart, J. (1997). Adam and Eve, not Adam and Henry. In R. M. Baird and S. E. Rosenbaum (Eds.), Samesex marriage: The moral and legal debate (pp. 30-31). NY: Prometheus Books.

Human Rights Campaign. (2004). Current marriage cases in the U.S. human rights campaign. Retrieved March 14, 2004 from

http://www.hrc.org/Template.cfm?Section=Center\&CONTENTID=15328\&TEMPLATE=/Conte ntManagement/ContentDisplay.cfm

Infanti, A. C. (1997). Baehr v. Lewin: A step in the right direction for gay rights. In R. M. Baird and S. E. Rosenbaum (Eds.), Same-sex marriage: The moral and legal debate (pp. 227-235). NY: Prometheus Books.

Judd, J. (1997). Testimony to the Hawaiian judiciary committee on sexual orientation, January 1997.

Lambda Legal. (2004). States with laws banning same-sex marriage. Lambda Legal Defense and Education Fund. Retrieved March 14, 2004, from http://www.lambdalegal.org/cgibin/iowa/documents/record?record $=1427$

Mohr, R. D. (1997). The case for gay marriage. In R. M. Baird and S. E. Rosenbaum (Eds.), Same-sex marriage: The moral and legal debate (pp. 84-104). NY: Prometheus Books.

Rawls, J. (1971). A theory of justice. Cambridge: The Belknap Press of Harvard University Press.

Roemer, J. E. (1996). Theories of distributive justice. Cambridge, MS: Harvard University Press.

Sullivan, A. (1997). Virtually normal. In R. M. Baird and S. E. Rosenbaum (Eds.), Same-sex marriage: The moral and legal debate (pp. 126-131). NY: Prometheus Books. 
Tuchman, G. (2004). Massachusetts governor urges calm on same-Sex issue. Retrieved March 14, 2004, from http://www.cnn.com/2004/law/03/12/mass.gay.marriage/index.html

\title{
Acknowledgements
}

The author would like to thank Todd Clear for his comments on an earlier version of this paper.

\author{
Author Information \\ Rhonda R. Dobbs \\ The University of Texas at Arlington \\ Department of Criminology and Criminal Justice \\ Box 19595 \\ Arlington, Texas 76019-0595 \\ E-mail: rdobbs@uta.edu
}

